\title{
In vitro STUDY OF IMPACT OF SELECTED FUNGICIDES AND PHYTOEXTRACTS ON MYCELIAL GROWTH OF Alternaria solani THE CAUSAL ORGANISM OF LEAF BLIGHT OF POTATO AND TOMATO
}

\author{
SUNIL PANDIT $^{\text {a1 }}$ AND L.P. YADAV ${ }^{b}$ \\ ${ }^{\mathrm{ab}}$ Department of Botany, Rajendra College, J.P. University, Chapra, Bihar, India
}

\begin{abstract}
Leaf blight of potato and tomato caused by Alternaria solani is an important fungal disease that causes heavy loss to the growers. In case of suitable conditions the pathogen causes maximum damage to these vegetable crops and even the fruits of tomato are also attacked by the pathogen. In the present study the pathogen was isolated and pure culture was maintained on Potato Dextrose Agar medium. In vitro experiments were done to evaluate the fungitoxic effects of three different concentrations of $\mathbf{7}$ selected fungicides as well as leaf extracts of $\mathbf{7}$ different plants extracts separately. Among the fungicides, 100 inhibition was found when $2000 \mathrm{ppm}$ of Difenconazole, Propinconazole and Benomyl was used. Diphenconazole and Propinconazole even at $1000 \mathrm{ppm}$, completely inhibited the mycelial growth of the pathogen in vitro. Lowest percentage of inhibition of mycelial growth was found in case of copper hydroxide. Even at $2000 \mathrm{ppm}$ the percentage of inhibition was 68.72 only. Similarly, Thiophenate at $2000 \mathrm{ppm}$ could inhibit the mycelial growth that was 78.85 only. Among the phytoextracts, leaf extract of Acasia nilotica at $30 \%$ inhibited 84.74 of mycelial growth, which was followed by the extract taken from the cloves of Allium sativa. At 30 the percentage of inhibition was 81.65. This was followed by the percentage of inhibition by leaf extract of Azadirachta indica, which were 78.54 at $30 \%$. Minimum inhibition at $30 \%$ of leaf extract of Phyllanthus niruri was 68.66 . In the present work it was noted that mycelial growth was inhibited at all the concentrations of the seven fungicides and leaf extracts of all the plants with different percentages of inhibition.
\end{abstract}

KEYWORDS: Leaf Blight, Fungicides, Phytoextracts, Mycelial Growth, Alternaria solani

Potato (Solanum tuberosum) and tomato (Lycopersicon esculentum Mill) are most remunerative and widely grown vegetables in the world. In some western countries potato is the staple food. Ganie et al., (2016) reported that potato is considered "The King" in food staples and hardly any domestic kitchen is available which does not use potato in one or other form as it possesses all the attributes to be a potential food crop. Kaur et al., (2004) reported that potato bears antioxidant properties and due to this it inactivates reactive oxygen species, reduce oxidative damage, lead to improved immune functions and reduce risk of cardiovascular diseases, cancer, cataract, diabetes and aging. Early blight, caused by Alternaria solani is a serious disease of potatoes. Pathogen causes heavy loss if the infection is severe. This may reduce the yield up to 20-50. This disease also causes dry rot of tuber that reduces the quality and quantity of marketable tubers. The pathogen over winters as mycelium or conidia in plant debris, infected tubers or on the alternative hosts. Lower leaves in contact with soil are generally infected first. From there the upper leaves and nearby plants are infected. The presence of the pathogen on infected plants can be recognized by the concentric rings on the necrotic patches.

The pulp and juice of tomato is very digestible, promoter of gastric secretion and blood purifier additionally it contains folates, potassium, vitamins A and C. Tomato has rank second next to potato in world acreage and ranks first among processing crops. It is being cultivated in 4.73 million hectares all over the world with production of 163.96 million tones and an average yield of 34.66 tones per hact (Kumar and Singh, 2017). The early blight disease caused by Alternaria solani is most important disease and may cause heavy damage in the yield (Saha and Das, 2012). From the survey of literatures, it was noted that different workers have tried to control the disease and have recommended certain fungicides. Similarly, phytoextracts have been used for its control. Some of them may be mentioned here. Mohan and Raveesha (2007), Lee et al., (2007), Saha et al., (2008), Venkataswamy et al., (2010), Zaheer (2010), Srivastva and Singh (2011), Dellavalle et al., (2011), Saran (2011), Shinde and Dhale (2011), Tapwal et al., (2011), Bhardwaj (2012), Gujar and Talwar (2012), Jagpat et al., (2013), Reddy et al., (2013), Sasodi and Singh (2013), Kantwa et al., (2014), Jha et al., (2014), all have used different plants extract to control the mycelial growth and sporulation of the above pathogens.

There are different workers who have tried to control this pathogen either through bioagents or chemical fungicides. Some of them are, Hamza et al., (2015), Waghe et al., (2015), Ganie et al., (2016), Ghazanfar et al., (2016), Rani et al., (2016), Devi et al.,

${ }^{1}$ Corresponding author 
(2017), Karalia et al., (2017), Kumar and Singh (2017), Shin et al., (2017), Hussain et al., (2018), Prasad et al., (2018). Keeping these ideas in mind present work was carried out to evaluate the efficacy of certain plant extracts and fungicides at different concentrations, separately for the inhibition of mycelial growth of Alternaria solani, in vitro.

\section{MATERIALS AND METHODS}

Alternaria solani was isolated from the infected leaves of tomato and potato. Pure culture of the fungus was maintained on the Potato Dextrose Agar medium. Seven plants, having medicinal values were located and their leaves were collected for the preparation of extracts. Leaves were washed thoroughly in the running tap water and dried properly. $100 \mathrm{~g}$ of above leaves was grinded in mortar and Pestle in $100 \mathrm{ml}$ sterilized distilled water.

The extract was filtered through four layered of pre-moistened muslin cloth. The final volume was adjusted to $100 \mathrm{ml}$ with distilled water. The extract was centrifuged at $5000 \mathrm{rpm}$ for $5 \mathrm{~min}$, and clean supernatant was used as stock solution. From this stock solution required amount was added in $100 \mathrm{ml}$ Potato Dextrose Agar medium before, it gelled to make the concentration 10, 20 and 30. So here, also poison food technique (Nene and Thapliyal, 1993) was used. Above sterilized and phytoextracts containing medium was dispensed in Petri plates in the aseptic condition in the cabin of Laminar air flow chamber. These plates were allowed to cool and were used for inoculation.

Seven different fungicides such as:

i. Difenconazole 25 EC - Trade Name : Score

ii. Propinconazole 25 EC - Trade Name : Tilt

iii. Carbindazin $50 \mathrm{WP}$ - Trade Name : Fungi Gamel.

iv. Mancozeb 75 WP - Trade Name : Dithane M-45

v. Benomyl $50 \mathrm{WP} \quad$ - Trade Name : Benlate

vi. Thiophenate Methyl 70 WP - Trade Name : Roko

vii. Copper Hydroxide - Trade Name : Kocide

Were purchased from the shop of Agrochemicals of Chapra town. Required amount of the chemical fungicides was dissolved to prepare concentration of 500 ppm, 1000 ppm, 2000 ppm. This was also added in pregelled Potato Dextrose Agar medium and then dispensed in the Petri plates on cooling these plates containing medium were used for inoculation.

\section{Inoculation}

Pure cultures of Alternaria solani maintained in the laboratory were used for inoculation. With the help of pre-sterilized cork borer, from the actively growing periphery region of the plate, $7 \mathrm{~mm}$ discs were cut with precautions. One such disc was transferred aseptically to the centre of each Petri plates, containing the poisoned solid medium.

These plates were incubated at $26 \pm 2^{\circ} \mathrm{C}$ in dark. Petri plates containing non-poisoned medium was also inoculated which served as control each treatment was replicated three times and in each culture 15 plates were inoculated. These cultures were watched on an alternate day and plates showing infection were discarded after autoclaving. The radial growth of the fungus in poisoned medium was recorded at the time when the radial growth of mycelium in control reached $91.60 \mathrm{~mm}$. The plates were turned upside down and a lien was drawn with the help of a marker from one end of the boundary of the mycelium to other end. This was measured to denote the radial growth.

Percent inhibition of radial growth in the poisoned medium was calculated by applying the formula:

$\mathrm{PI}=\mathrm{C}-\mathrm{T} / \mathrm{CX} 100$

Where,

$\mathrm{PI}=$ Percent inhibition

$\mathrm{C}=$ Radial growth in control

$\mathrm{T}=$ Radial growth in poisoned or treated medium with pytoextract/fungicides.

The mean of the data obtained has been represented by the graph 1 and 2 .

\section{RESULTS AND DISCUSSION}

\section{Evaluation of Phytoextracts}

Data obtained in the present work on in vitro efficacy of phytoextracts of different concentrations against Alternaria solani have been represented by the graph 1. From the graph it may be noted that there were significant difference with respect to fungitoxic effect of different phytoextracts at all the three concentrations, and was reflected by the percentage of inhibition of radial growth of the fungal pathogen. Among the phytoextracts taken separately from seven plant species, extract taken from Acasia nilotica was most effective at all its concentrations with respect to the inhibition of radial growth of the fungus in culture. Here the percentage of inhibition was 84.74 at $30 \%$ concentration, followed by 73.26 at $20 \%$ and 60.82 at $10 \%$ concentrations of the 
extract. This was followed by the extracts taken from the cloves of Allium cepa, which was 81.65 at $30,72.75$ at 20 and 60.18 at 10 concentration respectively. It may be noted form the graph that at similar concentrations of leaf extract of Azadirachta indica the percentage of inhibition was 78.54, 68.88 and 58.64 respectively. Minimum inhibition of radial growth of mycelium was inhibited by the leaf extract taken from the plants of Phyllanthus niruri at all the three concentrations followed by the leaf extracts of Ocimum sanctum that was 68.84, 61.18 and 55.76 respectively.



Graph 1: Showing percentage of inhibition of radial growth of mycelium of Alternaria alternata cultured in the medium poisoned with different concentrations of phytoextracts

\section{Evaluation of Fungicides}

Seven different fungicides at three different concentrations were assessed in vitro to determine the most effective fungicide against Alternaria solani. Here also poison food technique was applied and 500, 1000, $2000 \mathrm{ppm}$ of the all the seven fungicides were used separately. The data obtained are represented by the graph 2. It was found that Difenconazole $25 \mathrm{EC}$, Propinconazole $25 \mathrm{EC}$, Carbindazim $50 \mathrm{WP}$, at 1000 and 2000 ppm concentrations inhibited the radial growth of fungal mycelium 100\% and similarly, Benomyl $50 \mathrm{WP}$ at $2000 \mathrm{ppm}$, inhibited the radial growth that was $100 \%$. Therefore, among the seven fungicides, most effective fungicide was Difenconazole 25 EC which exhibited $100 \%$ inhibition of mycelial growth at 1000 and 2000 ppm. Even at $500 \mathrm{ppm}$ the percentage of inhibition was higher than rest of the fungicides at this concentration. Form the graph it may be noted that copper hydroxide at all the concentrations used revealed lowest percentage of inhibition in the radial growth of mycelium of the fungus in vitro.

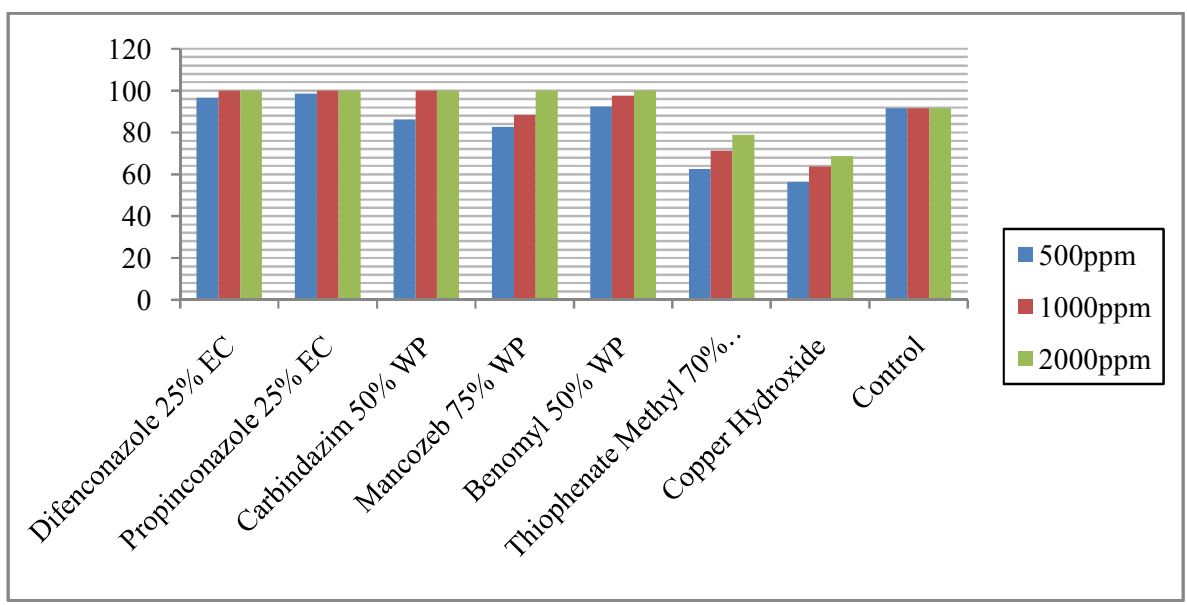

Graph 2: Showing percentage of inhibition of radial growth of mycelium of Alternaria alternata cultured in the medium poisoned with different concentrations of fungicides 
Efficacy of phytoextracts taken from different plants as fungitoxicant has been assessed by different workers. Okigbo and Ojbonuaya (2006), Satish et al., (2007), Chang et al., (2008), Saran (2011) Talibi et al., (2012), Zare et al., (2012), Sherwani et al., (2013), Singh and Srivastva (2013), Srinivas et al., (2013).

Singh et al., (2014), Hussain et al., (2015), Rathod et al., (2015), Mathivanan and V.R. Prabhavathy (2007), Nagegba et al., (2018), Chaudhary et al., (2019), Singh et al (2019). All these workers concluded that phytoextracts taken from different plants in general and medicinal plants in particular revealed fungitoxic activities at different concentrations. However, the quantum of activities varied which may be due to presence of different secondary metabolites. All these findings therefore, corroborate with the findings of the present work as here also the variations in fungitoxic effect was noted.

Different workers have also evaluated the efficacy of different fungicides at different concentrations to assay the efficacy in vitro. Rani et al., (2016), Theja and Devappa (2016), Kumar et al., (2017), Wagh et al., (2017), Prasad et al., (2018), have evaluated different concentration of selected fungicides against different fungal pathogen. Findings of present work are in agreement with the findings of these workers as the fungitoxic effect increases along with the increased concentrations. Similarly, all the fungicides do not inhibit mycelial growth at the same concentration.

It may be concluded that keeping the idea of impact of chemical fungicides on our environment, its cost and impacts on non-target organisms, it is essential to search an alternative agent to control the diseases of our crops. Phytoextracts are more potent candidate for it. Here among the fungicides Difenconazole $25 \mathrm{EC}$, Propinconazole 25 EC, Carbindazim $50 \mathrm{WP}$ and Benomyl may be more suitable fungicides. Likewise the phytoextracts from Acasia nilotica, Allium cepa, Azadirachta indica extracts may be preferred.

\section{ACKNOWLEDGEMENT}

The authors are thankful to Head, Department of Botany, J.P. University, Chapra for providing all the necessary facilities during this work.

\section{REFERENCES}

Bhardwaj S.K., 2012. Evaluation of plant extracts as antifungal agents against Fusarium solani (Mrt)sacc. World J. Agric. Sci., 8: 385-388.
Chang H.T., Chang Y.H., Wu C.L., Chang S.T., Chang T.T. and Su Y.C., 2008. Antifungal activity of essential oil and its constituents form Calocedrus macrolipis var. Formosa florin leaf against plant pathogenic fungi.

Chaudhary D.L., Khan M.S., Shah A., Yadav P. and Prasad A., 2019. Antifungal activity of three different ethanolic extract against isolates from diseased rice plant. Journ. of Analyt. Techni. and Res., 1: 047-063.

Dellavalle, P.D., Cabrera A., Alam D., Patricia L., Fernando F. and Riza M.D., 2011. Antifungal activity of medicinal plants extracts against phytopathogenic fungus, Alternaria sp. C. J.A. Res., 71(2): 231-239.

Devi O.N., Singh N.I., Devi R.K.T. and Chanu W.T., 2017. In vitro evaluation of Alternaria solani (Ellis and Mart) causing fruit rot of tomato by plant extracts and bio-control agents. Int. J. Curr. Microbiol. App. Sci., 6(11): 652-661.

Ganie S.A., Ghani M.Y., Hussain A., Ahangar F.A., 2016. Perpetuation of Alternaria solani of Potato under temperate Kashmir Valley condition. Molecular Plant Breeding, 7(25): 1-8.

Ghazanfar M.U., Raza W., Ahmed K.S., Qumar J., Haider N. and Muhmad H.R., 2016. Evaluation of different fungicides against Alternaria solani (Ellis \& Martin) Sorauer caused of Early blight of tomato under laboratory conditions. Int. J. of Zool. Studies, 1(5): 08-12.

Gujar J. and Talwar D., 2012. Antifungal potential of crude plant extract on some pathogenic fungi. World Journal of Science and Technology, 2: 58-62.

Hamza A.M., Mohmed A.A.A. and Derbalah A.S., 2015. Recent trends for Biocontrolling the tomato late blight disease under field conditions. Egyptian Journ. of Biol. Pest Control, 25(1): 145-151.

Hussain F., Abid M., Saukat S.S., Farzan and Akbar M., 2015. Antifungal activity of some medicinal plants on different pathogenic fungi. Pak. J. Bot., 47(5): 2009-2013.

Hussain S., Ayub M., Rasheed M., Hussain S., Hussain K., Hussain S.I., Hassan M., Hassain A., Hussain T., Imtiyaz M., Hussain A., Hussain S. and Riaz M., 2018. Efficacy of different 
fungicides against Alternaria tusi cause leaf blight of peas was first time discovered form Kharmang Olding and Skardu Baltistan. J. Entomology and Zoology Studies, 6(5): 22502260 .

Jagpat G.P., Mali A.K. and Dey U., 2013. Bioefficacy of fungicides, biocontrol agents and botanicals against leaf spot of turmeric incited by Colletotrichum capsici. African Journ. of Microbiol. Res., 7(18): 1865-1873.

Jha R., Regmi R., Sobita L., Simon and Lal A.A., 2014. Effect of six plant extracts on mycelial growth of Alternaria alternata causing leaf spot of Aloe vera. Int. J. of Res., 1(7): 1371-1373.

Kakraliya S.S., Choskit D., Pandit D. and Abrol S., 2017. Effect of bio-agents, Neem leaf extract and fungicides against Alternaria leaf blight of wheat (Triticum aestivum L.). Nat. Prod. Chem. Res., 5(8): 01-07.

Kantwa S.L., Tetarwal J.P. and Shekhawat K.S., 2014. In vitro effect of fungicides and phytoextracts against Alternaria alternata causing leaf blight of groundnut. Journal of Agricult. And Veter. Sci., 7(6): 28-31.

Kumar P. and Singh S., 2017. In vitro evaluation of fungicides and plant extract against Alternaria solani (Ellis) causing early blight in tomato (Lycopersicon esculentum). Int. J. Curr. Microbiol. App. Sci., 6(9): 820-827.

Kumar V., Singh G. and Tyagi A., 2017. Evaluation of different fungicides against Alternaria leaf blight of tomato (A. solani). Int. J. Curr. Microbiol. App. Sci., 6(5): 2343-2350.

Lee S.H., Chang K.S., Su M.S., Huang Y.S. and Jang H.D., 2007. Effects of some Chinese medicinal plant extracts on five different fungi. Food Control, 18: 1547-1554.

Mathivanan and Prabavathy V.R., 2007. Effect of carbendazim and Mancozeb combination on Alternaria leaf blight and seed yield in Sunflower (Helianthus annus L.). Archives of Phytopathology and Plant Protection, 40(2): 1-4.

Mohana D.C. and Raveesha K.A., 2007. Antifungal evaluation of some plant extracts against some plant pathogenic field and storage fungi. Journ. of Agricul. Technol., 4: 119-137.
Nene Y.L. and Thapliyal P.N., 1993. Fungicides in plant disease control IIIed. Oxford and IBH Publishing Company Pvt. Ltd. Callots Page 531.

Ngegba P.M., Kanneh S.M., M.S. Bayon, Ndoko E.J. and Musa P.D., 2018. Fungicidal effect of three plants extract in control of four phytopathogenic fungi of tomato (Lycopersicum esculentum L.) fruit rot. Int. J. Env. Agric. and Biotech., 3(1): 112-117.

Okigbo R.N. and Ogbonnaya U.O., 2006. Antifungal effects of two tropical plant leaf extract (Ocimum gratissimum and Aforomomum meleganta) on post harvest yam (Dioscorea Sp.) rot. Afr. J. Biotechnol., 5(9): 727-731.

Prasad B.M.V.S., Bhattiprolu S.L., Kumari V.P. and Kumar P.A., 2018. In vitro evaluation of fungicides against Alternaria macrospora causing leaf spot in cotton. Int. J. Curr. Microbiol. App. Sci., 7(1): 2551-2557.

Rani N., Lal H.C., Kumar P., Ekka S. and Kumar N., 2016. In vitro evaluation of fungicides, bioagents and plant extracts against Alternaria sp. infecting pigeon pea. Int. J. Curr. Microbiol. App. Sci., 7: 5112-5118.

Rathod M.C., Vaishali J., Godhani and Dhale D.A., 2015. Antifungal activity of some medicinal plant material extract against fungus Aspergillus niger. World J. Pharmacy and Pharmaceutical Science, 4(10): 1323-1332.

Reddy R.R., Krishna K.C., Lokantha O., Mamtha S., Reddy C.D., 2013. Antimicrobial activity of Azadirachta indica leaf, bark and seed extracts. Int. J. Res. Phytochem. Pharmacol., 3(1): 1-4.

Saha D., Dasgupta S. and Saha A., 2008. Antifungal activity of some plant extracts against fungal pathogens of Tea (Camellia sinensis). Pharmaceutical Biology, 43: 87-91.

Saran Raj. P., 2011. Pharmacological screening of Datura metal and Acalypha indica for its antifungal activity against pathogenic fungi. Int. J. Pharmaceut. Sci. Health Care, 1: 38-44.

Sasode R.S. and Singh P., 2013. Antifungal evaluation of Calotropis leafy extracts against some plant pathogenic fungi. Trends in Biosci., 6(1): 82-85.

Satish S., Mohana D.C., Raghavendra M.P. and Raveesha K.A., 2007. Antifungal activity of some plant 
extracts against important seed borne pathogens of Aspergillus Sp. Journ. of Agricult. Technol., 96: $563-568$.

Sherwani S.K., Bokhar T.Z., Azim K., Gilani S.A. and Kazmi S.U., 2013. Qualitative phytochemical screening and antifungal activity of Carica papaya leaf extract against human and plant pathogenic fungi. Int. Res. J. of Pharmacy, 4(7): 83-86.

Shin J.H., Fu T., Park K.H. and Kim K.S., 2017. The effect of fungicides on mycelial growth and conidial germination of Ginseng root rot fungus Cylindrocarpon destructans. Microbiology, 45(3): 220-225.

Shinde V. and Dhale D.A., 2011. Antifungal properties of extracts of Ocimum tenuiflorum and Datura stramonium against some vegetable pathogenic fungi. Journal of Phytology, 3(12): 41-44.

Singh G., Gupta S. and Sharma N., 2014. In vitro screening of selected plant extracts against Alternaria alternata. Journ. of Experimental Biol. and Agric. Science, 2(3): 344-351.

Singh J., Bhatnagar S.K. and Tomar A., 2019. Study on fungicidal effect of plant extracts on preparation and efficacy in comparison to synthetic/ chemical fungicides. J. Appl. \& Nat. Sci., 11(2): 333-337.

Singh P. and Srivastva D., 2013. Phytochemical screening and in vitro antifungal investigation of Parthenium hysterophorus extracts against Alternaria alternata. Int. Res. Journ. of Pharmacy, 4: 190-193.

Srinivas P., Ved R. and Reddy N., 2013. In vitro evaluation of fungicides, biocontrols agents and plant extracts against rice sheath blight pathogen Rhizoctonia solani. Int. Journ. of Pharma. Technol., 5: 121-126.

Srivastva D. and Singh P., 2011. Antifungal activity of two common weeds against plant pathogenic fungi Alternaria Spp. Asian Journ. of Expeirmental Bioscien., 2: 525-528.
Talibi I., Askarne L., Baubaker H., Boudyaeh E.H., Masande F., Saadi B. and Aumaar A.A.B., 2012. Antifungal activity of some Maraccan plants against Geotrichum candidum, the causal agent of post harvest citrus sour rot. Crop. Protection, 35: 41-46.

Tapwal A., Garg N., Gautam N. and Kumar R., 2011. In vitro antifungal potency of plant extracts against five phytopathogenic. Brazilian Archieves of Biology and Technology, 54: 1093-1098.

Theja Kumar M.B. and Devappa V., 2016. Efficacy of different fungicides against Alternaria alternata and Cercospora capsici under in vitro conditions. Int. J. of Adv. Res. in Biol. Sci., 3(5): 126-129.

Venkataswamy R., Doss A., Sukumar M. and Mubarak H.M., 2010. Preliminary phytochemical screening and antimicrobial studies of Lantana indica Roxb. Ind. J. Pharm. Sci., 72: 229-231.

Wagh S.S., Suryawanshi A.P. and Pawar D.V., 2017. Efficacy of fungicides, bioagents and phytoextracts against Alternaria carthami of Safflower in in vitro condition. J. of Pure and Appl. Microbiol., 11(3): 1589-1598.

Waghe K.P., Wagh S.S., Kuldhar D.P. and Pawar D.V., 2015. Evaluation of different fungicides, bioagents and botanicals against Alternaria blight caused by Alternaria helianthi (Hansf) of Sunflower. African J. of Agricult. Res., 10(5): 351-358

Zaheer M.M.H., 2010. Antifungal activity of some plant extracts on Alternaria alternata the causal agent of leaf spot of Potato. Pakistan J. of Biological Sci., 13: 1023-1029.

Zare Z., Ahmad M., Saffari T.N., Alireza I. and Sedigne M., 2012. Antimicrobial activity of leaf and flower extract of Lippia nodiflora (Verbenaceae). J. of Plant Protect. Res., 52(4): 01-03. 